\title{
The 'Fool's Cap' map of the world: exploring critical cosmopolitanism through cartographic critique
}

\section{Alison Hulme}

\author{
University of Northampton, Northampton, UK
}

\begin{abstract}
The 'Fool's Cap' map of the world is thought to date from the late sixteenth century and is often attributed to a little-known Christian sect called the Family of Love, or 'Familists'. It places a map of the world in the place of a face inside a jester's cap, playing upon the subversive figure of the jester and his ability to ridicule the pomposity of those in control. The 'Fool's Cap' map then, is a view of the world that speaks to, and challenges, power relations. The Familists were neo-Stoic in their outlook and cosmopolitan in that they valued the idea of the world citizen. However, appalled with the governments of their day, they insisted upon self-reflection, in ways not dissimilar to contemporary scholars engaged in 'critical cosmopolitan'. This article analyses the interplay of ideas of charity, theatre of the world, and neo-stoicism seen in the map, and makes a case for viewing the Familists and their thinking as an early form of critical cosmopolitanism - a cosmopolitanism that attempts to critique its own culture whilst maintaining a belief in what constitutes a good ethical world citizen. In doing so it engages with the debates around cosmopolitan forged by thinkers such as Martha Nussbaum and Gerard Delanty, and links these to the idea of emancipatory potential of globalization as advanced by Leslie Sklair.
\end{abstract}

\section{Introduction}

As David Inglis asserts, there are many histories of cosmopolitanism, most of which tend to trace a line from the ancient Greeks to the present with the key moments typically being posited as Greek Cynicism and Stoicism (Nussbaum, 1997); the Roman adaptation of these ideas (Pollock, 2002); the Enlightenment philosophers of cosmopolitanism, namely Kant (Schlereth, 1977); and the cosmopolitan concerns that resurfaced after World War II in the creation of institutions such as the UN (Friedrich, 1947) (Inglis, 2012, pp. 11-12). However, this narration, Inglis argues, should not be taken as an unexamined truth, lest it lead to orthodoxies, the reproduction of unquestioned verities, and a lack of useful scepticism and self-understanding of the field (Inglis, 2012, p. 12).

This failure to engage in self-reflection has seen cosmopolitan studies as a discipline become increasingly concerned with its own history of moralism, as embedded within a certain subject position. Arguably, 'critical cosmopolitanism' is an attempt to rid the field of this privileged, morally superior, subject position. Critical cosmopolitanism is usefully defined by Gerard Delanty as a cosmopolitanism that is about critique and transformational potential (2012). As Delanty asserts, the general characteristics of cosmopolitanism include 'centrality of openness and overcoming of divisions; the interaction; the logic of exchange, the encounter and dialogue; deliberative communication; self and societal transformation (transformational); and critical evaluation' (Delanty, 2012, p. 41). Together, these characteristics enable a definition of cosmopolitanism 'as a condition of openness to the world and entailing self and societal transformation in light of the encounter with the Other' (2012, p. 41). Critical cosmopolitanism can be distinguished from other uses of the term cosmopolitanism by its critical and transformative nature, as invoked by scholars such as Mignolo (2000) who argues it is a post-colonial critique of Eurocentric assumptions; and Rumford $(2008,2013)$ 
who sees it as causing the subject to question their own positionality (often as holder of rational or civilized thought).

This article attempts to engage with this critique by taking a cartographic representation and using it as a vehicle to think through some of the debates and dilemmas facing critical cosmopolitanism. The Fool's Cap map (FCM) is thought to date from the late sixteenth century (c. 1590), and is often attributed to a little-known Christian sect called the Family of Love (or 'Familists'), although the actual author of the map is the subject of much speculation. It places a cordiform (heart-shaped) map of the world in the place of a face inside a jester's cap, playing upon the subversive figure of the jester and his ability to ridicule the pomposity of those in control (see Figure 1). The FCM then, is first and foremost a view of the world that speaks to, and challenges, power relations. It could be seen as an example of what critical cartographers such as J. B. Harley ${ }^{1}$ call counter-mapping - maps that aim to expose the hidden agendas of cartography and power relations.

The projection of the FCM resembles the earlier cordiform projection created by Abraham Ortelius in his 1564 map of the world (see Figure 2). However, as Giorgio Mangani ${ }^{2}$ attests, this projection was not the first of its kind. In 1511, Bernardus Sylvanus's version of Ptolemy's general map of the world, had bent the upward curves of Ptolemy's projection into 'something approaching a heart shape'. Giovanni Vavassore had made a woodcut map, sometime between 1520 and 1540, based on Sylvanus's map. And in addition, Oronce Fine had created two cordiform projections, one single, one double. These gave rise to a tradition of similar maps throughout the sixteenth century, such as Peter Apian's Tabula orbis coßtiiti (1530) and Gerard Mercator's maps of 1538 (Mangani, 1998, p. 59). Abraham Ortelius's cordiform map then, was the latest in a line of such maps when it was used in the FCM. Moreover, mapmakers such as Fine, Mercator and Ortelius, as well as their friends and colleagues were contemporaries who 'neither worked nor lived in isolation from each other', and shared many spiritual and intellectual ideas (Mangani, 1998, p. 59).

The cordiform map had particular significance in the sixteenth century and its creators can all be linked to a sixteenth century movement, popular in England and the Low Countries (as they were then known), called Familism. This movement was founded by Hendrik Niclaes in about 1540 and developed among intellectuals, collectors, antiquarians, artists, merchants and bankers, including Abraham Ortelius. Familist beliefs were based on a highly individualistic spirituality which saw no place for ceremony, rather, seeking a direct dialogue with God based on inner 'illumination', rather like the Quakers. Also like Quakers, Familists 'were unconcerned with differences between faiths', and welcomed Catholics, Muslims, Jews or members of Reformed or Evangelical churches into their folds (Mangani, 1998, p. 72). Essentially, the vision of Familists was to create an invisible global church through which all people of faith could speak directly to God. Therefore, in common with the Jesuits, Familists were keen to teach their faith to other cultures (Mangani, 1998, p. 72).

Philosophically, the Familists were neo-Stoic as will be explored in what follows. As Inglis argues, 'any treatise on the history of cosmopolitan thought contains depictions of its beginnings in ancient Greece and its Cynic and Stoic origins', via the figure of Diogenes declaring himself to be a citizen of the world (Inglis, 2012, p. 13). This article too, begins with Diogenes and his appearance on the FCM, but via neo-Stoic self-reflection, and ends in a rather more radical position vis-à-vis the Other than some orthodox histories tend to. An engagement with the frequently heated debates around Martha Nussbaum's position, is therefore inevitable, as she has been largely responsible for the creation of contemporary discussions around ancient cosmopolitanism. In doing so, this article aims to speak 
specifically to how critical cosmopolitanism might serve in the context of a globalized and globalizing world. In this sense, it takes inspiration from Leslie Sklair's idea of 'generic globalization' and its emancipatory potential, discussed in this journal (Sklair, 2009). Essentially then, this article suggests the FCM can be interpreted as an early example of what has since been conceived of as critical cosmopolitanism, and that it might provide inspiration for honing the direction of critical cosmopolitanism and indeed its potential for claiming globalization as an emancipatory force in the face of transnational capitalism.

\section{The theatre of the world and cosmological world views in the Fools' Cap map}

The FCM plays upon an idea that was well known at the time of its creation - the 'Theatre of the World' (theatrum mundi). In the late sixteenth century, the word 'theatre' appeared in the titles of illustrated works on human anatomy, animals, plants, machines, and instruments. Metaphorical use of 'theatre' was also closely connected at this time to the architecture and design of actual theatres which were seen as spaces of 'sweet reason' - logical understanding of the world constructed and conveyed through the power of beauty and words. ${ }^{3}$ However, 'vulgar' forms of theatre (such as ancient ampitheatres and circuses) were seen, in their ruin, as proof of the vanity of human endeavour. Therefore, 'metaphorically and materially, the theatre was a powerfully moralized space, capable of generating strongly opposing polemics' (Cosgrove, 2003, p. 858). Essentially, the Theatre of the World is a vision of the globe as a vast stage upon which the drama of human existence is played out.

At the time of the FCM various civil wars were on-going in Europe and the Familists despaired at the irrational and cruel behaviour they witnessed in their times. Familism came to hold particular appeal for educated and cosmopolitan thinkers, many of whom were appalled by the intolerance of religious fanaticism they saw played out both within Europe and in Spain's New World Empire. Indeed, as Delanty points out, the history of cosmopolitanism has frequently been concerned with war and violence (2012, p. 43). ${ }^{4}$ Mangani argues the FCM was undoubtedly intended to display the comic and grotesque nature of human life, especially in this context of the absurdity of national wars and civic conflict. In particular, he points to how the part of the fool's head that does not contain the map, is embellished with the 'grotesque attributes' of the fool's calling - 'ass ears, little bells and staff'. He also notes that other bits of text on the map fit the theme of 'contemptus mundi' (contempt for the world) (Mangani, 1998, p. 69). For example, the longest text reads 'Hic est mundi punctus et materia gloriae nostrae, hic sedes, hic honores gerimus, hic exercemus imperia, hic opes cupimus, hic tumultuatur humanum genus, hic instauramus bella, etiam civilia. Plin.' 'This is the place and the nature of our glory, here we have honour, manage power, wish wealth, here the human race riots, here we make wars, even civil ones.' [Pliny]. On each of the round medals forming the fool's collar is written, in turn, 'O curas homunum' [Oh human ambitions]; 'O quantum est in rebus inane' [O how empty is this life]; 'Stultus factus est omnis homo' [Each man has become stupid]; and 'Universa vanitas omnis homo' [Each man is a whole vanity]. Finally, on the cap's ears is a phrase from the stoic philosopher Annaeus Cornutus that reads 'Auriculus asini quis non hebet' [Who does not have donkey's ears?].

The notion of the theatre of the world comes from Ortelius's Theatrum Orbis Terrarum, which became the model for seventeenth-century atlases, and therefore the prototype for the modern atlas (Cosgrove, 2003, p. 855). ${ }^{5}$ However, it can usefully be traced to the work of a printer closely associated with the Familists - Niclaes Bombarghen. In 1576 Bombarghen produced a devotional 
image, which was widely but secretly distributed among Familists (see Figure 3), that featured a soul searching for the road to lost paradise through a set of dangers and potentially fatal diversions. The choice given in the print is that between a narrow door and a wide door; symbolism used frequently by the Familists to portray ethical and religious choice. Familism revived the 'theatre of the world' notion not only as a metaphor for the miserable condition of humanity, but as a way of stating that humankind can only aspire to spiritual salvation through its behaviour while briefly on earth - by choosing the 'right' path, or in this case door.

As well as providing a stage for the absurd dramas and ethical choices of the world, the Theatre of the World was also a cosmographic concept. As Cosgrove states, it 'connects the elemental earth to the order and movement of heavens within a single, ordered, and harmonious creation'- in other words a cosmos $(2003$, p. 856). The cosmographic nature of the concept of the Theatre of the World is important in an analysis of the FCM as a vehicle for thinking about critical cosmopolitanism. As Heikki Patomaki explains, 'critical cosmopolitan orientation has usually been embedded in a non- geocentric physical cosmology that locates the human drama on the surface of planet Earth within wide scales of time and space' (2010, p. 181). This has enabled critical cosmopolitanism to inhabit a contrasting position to that of centric cosmologies (such as that of Aristotle for example), which see the world as revolving around a specific observer, theorist, or communal identity (2010, p. 181). Indeed, Patomaki describes critical cosmopolitanism as detached - as not coming from a specific nation that purports to know best, or makes claims to a moral universalism (2010, p. 182). Just as critical cosmopolitanism does not have a single subjective position, the FCM too is based on a non-geocentric physical cosmology. The physical earth represented is indistinguishable in terms of viewing perspective; and indeed politically the subject position of its supposed creators (or supporters at least) is spread amongst an international 'family' of like-minded thinkers.

\section{Charity, free will, and the potential for transformation in the Fool's Cap map}

Absolutely key to the Familists vision for the world was the practice of charity. Therefore, Familist iconography typically portrayed the burning heart - a symbol of charity, love for others, and the divine force of illumination. The heart had been portrayed as a symbol of charity since the thirteenth century, such as in Giotto's paintings in the Arena Chapel, Padua, and in Andrea Pisano's paintings in the cathedral baptistery and campanile in Florence. As Mangani points out, an illustration showing a burning heart containing three lilies and two hands clasped in a handshake, with Hebrew characters spelling 'Yaweh' and sometimes the word 'Verity' or 'Love' and the motto 'charitas extorsit', appears frequently in works by Niclaes and other Familist texts (1998, p. 72). The heart represented the place of moral choice - it was seen as representing the centre of the universe, so was about ethical choices at the centre of existence (Mangani, 1998, p. 66). Familists felt those who Believed would find their heart filled with charity by God. According to the Familists, life made no sense without faith, and the ancient Delphic motto 'nosce te ipsum' [know thyself] is engraved at the top of the map in place of a title. However, placing the projection of the world on the heart, meant that it was not simply charity that was contained within the symbol, but the plight of charity in the world. The cordiform map was about the will of people to act charitably, and their ethical choices in the world.

Choice itself was a highly important concept and Familism was committed to the idea of free will. In fact, the metaphor of Theatre of the World would become embroiled in 'one of the most important arguments which antiquity bequeathed, substantially unresolved, to the Christian Renaissance: that of free will and its relations to a divine providence' (Mangani, 1998, p. 42). This debate fuelled one of the 
most notable encounters of the sixteenth century - the debate between the Erasmians and the Lutherans, which produced violent strife in virtually every region of Europe (Mangani, 1998, p. 42). ${ }^{6}$ Familist philosophy however found religious expression in the quietist rejection of both extremes of Calvinism and Catholicism. As the map shows, human life is conducted at the very centre of the world machine, in the elemental sphere of transience and corruption. But humans - uniquely - are given the capacity to rise, in spirit, above earth's elemental surface toward the ethereal spaces of the celestial realm and to gain an angelic perspective. Familist neo-Stoicism seemed to offer a third way between the blind acceptance of authority expected by Rome and the Protestant predetermination preached in Geneva. This third way was via divine Providence, which could mediate between blind fate and human self-shaping. This was not dissimilar to Erasmus's 'middle road' (via media) at the time; indeed Erasmus, rather than Luther, was the Familist's guiding thinker. ${ }^{7}$

What is crucial about the idea of free will in the FCM in the context of critical cosmopolitanism is that it was fundamentally linked to the idea of transformation in society via an engagement with the Other. Critical cosmopolitanism is built upon the views of the Other as well as global principles of justice (Delanty, 2012, p. 41). The FCM inherently enables a view of the Other due to inverting the logic of the governments of the day by placing them inside the jester's head. By suggesting all may not be so logical, it automatically welcomes in something Other and attempts to use that for the purposes of societal transformation. In this sense the FCM precisely fits the way in which Delanty describes critical cosmopolitanism as a critical attitude that can be understood in two senses. Firstly, as a critique of other conceptions of cosmopolitanism, and secondly (and more importantly), as 'an account of social and political reality that seeks to identify transformational possibilities within the present' (Delanty, 2012, p. 38). The FCM, through its theatre of the world motif, was certainly a critique of non-cosmopolitanism and other forms of cosmopolitanism of the day, but it also attempted to actually transform society in its hopeful placing of charity and free will at the centre of existence.

This can be read as an incitement to take responsibility for the unfolding of history on the planet and, through human endeavour, to transform how this history manifests itself. In both the FCM and the account of critical cosmopolitanism, the encounter with the Other has the function, developed by Honneth, of broadening one's horizons in order to be able to take into account the perspective of the Other. The idea, developed by Honneth, is that new ways of seeing the world emerge out of the critical encounter of different viewpoints as part of a 'disclosing critique' (2000 , p. 40). In fact, as Delanty argues, the contemporary relevance of cosmopolitanism consists of its 'critical significance as both an analysis of social and political problems and as an account of the social world in terms of immanent possibilities for transcendence [my italics]' (2012, p. 45). Essentially, both critical cosmopolitanism and the FCM view the social world as possessing transformative possibilities that are located within the present but are future-oriented.

For critical cosmopolitanism, much of this transformation is about enabling cosmopolitanism to address the problems of a globalized world in which globalization has not provided a more just world or a better life. This ability to critique globalization is precisely why critical cosmopolitanism is perfectly compatible with notions of 'rooted cosmopolitanism' and more generally with conceptions of cosmopolitanism that seek to relate cosmopolitanism to socially contextualized situations (Delanty, 2012, p. 45). It is at this juncture that critical cosmopolitanism finds itself pitted against Martha Nussbaum's statements against rooted cosmopolitanism in favour of a subjective position that echoes Diogenes famous statement. However, where critical cosmopolitanism differs from such approaches is 
in its concern with the identification of moments of self-transformation due to encounter with the Other. In fact, in both the FCM and critical cosmopolitanism, the subject is de-centred.

This de-centering is useful to transformative action in exactly the sense Chris Rumford captured with the idea of globalizing strangeness. For Rumford, strangeness was about the past surety of the categories of 'them' and 'us'; and of the fading sense that 'we' are definitely not the strangers in 'our' own society (Rumford, 2013). The new kind of 'stranger' that Rumford's work tried to explain, was one who felt themselves to be at home, and yet, not at home, everywhere. This meant one no longer knew if one were a stranger or not, or indeed who 'us' and 'they' were - a 'generalized condition of societal strangeness' in which such differentiations are increasingly problematic (2013). Rumford goes on to talk about 'globalization moments', in which an individual suddenly feels the forces of globalization 'bearing down' on their lives' $(2013$, p. 10). It is these moments that can be seen as transformative both for the individual and for society.

Such globalization moments can be usefully understood in the context of Leslie Sklair's four phenomena of generic globalization; moments in both the temporal sense and terms of them being social forces, that have come to be of increasing significance since the mid-twentieth century (Sklair, 2009 , p. 527). These four phenomena are: 1 ) the electronic revolution, notably transformations in the technological base and global scope of the electronic mass media and the rise of the network society (the electronic moment); 2) postcolonialisms (the postcolonial moment); 3) the sub- sequent creation of transnational social spaces (the spatial moment); 4) qualitatively new forms of cosmopolitanism (the cosmopolitan moment) (Sklair, 2009, p. 527). Sklair argues that from the point at which capitalism began to globalize in the second half of the twentieth century, the emancipatory potential of generic globalization has been systematically undermined. This is due to a relatively straightforward relationship between generic globalization and capitalist globalization in which transnational corporations have seized the potential of generic globalization, turning opportunities into private profit and thus challenging its emancipatory potential (2009, p. 529).

However, despite this acknowledgement of the power of capitalist globalization, Sklair's major thrust is that that transformative potential of globalization can be reclaimed and re-harnessed (2009, p. 527). To relate his much longer globalization 'moments' to Rumford's more everyday and discrete 'moments' is to recognize that both contribute to the potential to trigger transformation through the individual's awareness of their position within a globalized world. Essentially then, this positionality relates to the extent to which the subject experiences themselves as a cosmopolitan, and in what sense this is the case for them. An engagement with the Other, or to put it in Rumford's terms, a recognition that it is no longer so simple to define what is Other, when faced with such 'moments', is essentially a moment of choice not dissimilar to that which the FCM attempted to illustrate. It is a moment of critical self-awareness. Specifically, this critical self-awareness is embedded in the subject's relation to 'qualitatively new forms of cosmopolitanism', by which is meant capitalist cosmopolitanism in which the prevailing logic is that the culture-ideology of consumerism works best in a peaceful, if competitive environment, and that therefore war and violence are not sustainable drivers of capitalist globalization (2009, pp. 533-534). Of course, as Sklair points out,

the simple idea that doing business with other people is a good in itself conceals the reality of what doing business under the conditions of capitalist globalization actually entails, namely exacerbating the twin crises of class polarization and ecological unsustainability (2009, pp. 533-534). 
As Sklair argues, at is philosophical roots, 'the common theme that runs through all these ideas [of cosmopolitanism] is the difficult necessity of building a world in which people live at peace with one another, accepting differences without fear or hatred' (2009, p. 533). Viewed in this light, the FCM's emphasis on ethical choice and free will in the context of unjust war becomes cuttingly apposite. As Sklair asserts, 'this is precisely why thinking about new forms of cosmopolitanism has to be an urgent task for those who attempt to conceptualize alternative forms of non-capitalist globalization' (2009, pp. 533-534).

\section{Neo-stoicism as a cosmopolitan outlook in the Fool's Cap}

So far two images and concepts contained in the FCM have been explored; the earth as a stage, and the heart as fount of charity, human spirituality, and free will. As Mangani argues, these concepts 'converged to become places where the dramas of ethical and spiritual choice were located' (Mangani, 1998, p. 60). However, placing these two elements in a joker's head gives another layer of meaning; it emphasizes the extent to which the Fool's Cap map, is not a straight-forward Stoic take on world affairs, but a neo-Stoic one, that asks us to reflect on ourselves, as well as others.

Classical Stoicism held that the universe was a rational creation - a logos, comprehensible to humans as the only creatures to share with their creator the capacity for reason. The goal of human life was to cultivate reason, understand the world, and, through nurturing virtue, overcome the limitations of physical nature and the vagaries of fate. This implied loosening the ties of local attachments (ethnos, gender, and so on) to follow Diogenes' claim of citizenship 'of the world' (kosmou polites). The practical application of Stoic principles to civil society was most powerfully articulated by Cicero, whose writings had gained respect and influence among fifteenth-century humanists, attracted by the quality and clarity of his Latin. In contrast to Aristotle's division of humans (i.e. freeborn, adult, male Greeks) from barbarians 'born to slavery', Cicero's Stoicism regarded all the world's people as human because they shared three attributes: the capacity for reason, the ability to grasp the divine, and the potential for sociability. According to this argument, it becomes the task of the philosopher and the poet, through rational discourse and the persuasive power of words - 'sweet reason', rather than force and aggression - to bring all into cosmopolis, the unitary family of civilized people, represented for Cicero by the highest principles of the Roman republic.

Neo-Stoicism was a philosophy derived from Stoicism that emerged in the late fifteenth century, and owed much to the humanist study of Cicero, Seneca, and other Latin authors. It was effectively an attempt to revive ancient Stoicism in a form that would be acceptable to a Christian audience. The key text was Justus Lipsius's De Constantia ('On Constancy') of 1584. Neo-Stoicism shared a belief in reason and the scholarly life, preaching patience, tolerance, and forbearance in the face of life's adversities, as well as a detachment from the human condition. However, neo-Stoics acknowledged the free will of the human, and were concerned with the freedom that could be attained if one were not overcome by the 'passions'. This meant more focus on the inner dimension of spirituality, and much self-questioning.

It should be noted that neo-Stoicism was essentially a Renaissance view, and much has been written about the Enlightenment geography that followed and how this influences contemporary ideas on cosmopolitanism and globalization. Most usefully for the argument in this paper, David Harvey, in 2000, argues that the Renaissance tradition of geography as 'everything understood in terms of 
space', was 'squeezed out' by the Enlightenment tradition which was concerned with 'a scientific, disciplinary regulation of knowledge, which, he claimed, reduced the geographical project to administering empire, mapping and planning land uses and territorial rights, and gathering and analyzing useful data for the purposes of business and state administration. Harvey highlights passages from Kant's lectures on physical geography in which he shows typical European prejudices toward the customs and habits of stereotyped peoples in other parts of the world (2000, p. 533).

In addition, as Cosgrove points out, such prejudices were given added authority by 'Enlightenment attempts at naturalistic explanation and spatial correlation of instrumented physical and human geographic distributions' (2003, p. 866). Certainly, the shift in emphasis from the Renaissance to the Enlightenment were considerable. As Cosgrove puts it, 'the intellectual connections between cosmography (later geography) and cosmopolitan tolerance were severely challenged by other, practical and often less nobly motivated roles embraced by geographers during the long centuries of European global dominance'. Eighteenth-century geography separated from cosmography to become a discourse of state-making, and with Reason (now appropriately capitalized) no longer the spark of divinity in human creatures but a sovereign European achievement and the measure of European superiority over 'natural man', cosmopolitanism and geography were less easily twinned (2003, p. 866).

In the mid-1990s Cicerian Stoicism (i.e. the original Stoicism, rather than the neo-Stoicism of the Renaissance) was to undergo a controversial revival through the work of Stephen Toulmin who argued for the centrality of cosmopolitanism in the construction of modernity (1990); and then via Martha Nussbaum who argued for the reinstating of cosmopolitanism as Toulmin conceived of it (1996). Her plea (whilst informed by late-twentieth-century pluralism and globalization) was directly related to Diogenes's statement about being a citizen of the world. This view of being a world citizen was one that had become specifically associated with Stoicism. Nussbaum believed, as did Diogenes, that specific and local attachments to family, community, ethnos, or religion should not be considered more important than membership of a universal humanity. ${ }^{8}$ Her concern was with reasserting world citizenship in the face of local rights claims, gender and identity politics, and rationality, all of which strongly emphasized attachment to place.

Nussbaum's statements produced critical responses from many writers ( most notably Richard Sennett, in Christian cosmopolitanism (1994). ${ }^{9}$ Many were concerned about the homogenizing nature of cosmopolitanism in the essentially Kantian form Toulmin had conceived of it, and its Western, Christian, etc. assumptions. (See Kant's essay on Perpetual Peace.) ${ }^{10}$ Certainly, Nussbaum makes no apologies for this Kantian influence. She acknowledges that it became fashionable to look to the ancient Greeks 'for alternatives to the Enlightenment and its idea of a political life based on reason' and that for many philosophers an alternative paradigm was to be found in the ancient Greek polis based 'less on reason and more on communal solidarity, less on principle and more on affiliation, less on optimism for progress than on a sober acknowledgment of human finitude and mortality' (1997, pp. 1-2). For Nussbaum however, Kant, the arch-foe of these alternative-seeking thinkers, defended a truly universal politics that was active, reformist and optimistic. She explicitly states that her aim is to 'trace the debt Kant owed to ancient Stoic cosmopolitanism' and recognize that through him Seneca, Marcus Aurelius, and above all Cicero present us with the 'noble and practical' challenge of providing a paradigm to inform our engagement with political life in the context of ethnic violence, genocidal wars and widespread disregard for human dignity (1997, pp. 3-4.) Essentially, for her, and for Toulmin, just as it was for the Stoics, whilst this did not mean one needed to ignore one's local 
affiliations, it did require that 'we should regard our deliberations as first and foremost, deliberations about human problems ... not problems growing out of a local or national identity that confines and limits our moral aspirations' (Nussbaum, 1997, p. 9).

In contrast to what many have interpreted as a Kantian view of cosmopolitanism, the FCM appears to operate at a critical distance, enabling a neo-Stoic view, that sits more comfortably with current-day critical cosmopolitanism. To the left of the jester's head as we look at it, is a plaque that makes reference to the Stoics Heraclitus and Democritus; it says 'Democritus abderites deridebat' [Democritus of Abdera laughed], 'Heraclitus ephesius desiebat' [Heraclitus of Ephesus wept]. Democritus is represented supporting a globe and smiling at human folly; Heraclitus wrings his hands and weeps for the sufferings of humans subjected to the 'slings and arrows of outrageous fortune.' The philosophers' faces translate easily into the conventional theatrical masks of comedy and tragedy and thereby connect the image of the earthly globe to themes of vanitas and human folly. However, the anonymous map-maker also introduces himself on the map, importantly, as a follower of Epictetus, thus distancing himself from Heraclitus and Democritus in order to present a different moral attitude - the neo-Stoic view of the individual's inner dimension. As Cosgrove argues, 'while Democritus shows contempt, and Heraclitus feels pain, for their fellow citizens, the mapmaker has chosen cosmopolitanism'. What is crucial to recognize here, is that this cosmopolitanism is depositioned, due to the map being placed inside the jester's hat. The cosmopolitan subject is looking at the world from an indefinable position, removed from any geographic or political logic. This is not then the Stoic view of a cosmopolitan in the Kant/Toulmin/Nussbaum vein who is localized but primarily a world-citizen; it is the an avowedly neo-Stoic view of a cosmopolitan who is neither local nor global - who floats free as it were.

Seen in the context of these debates, the FCM enables a reconsideration of dominant (sometimes 'cosmopolitan') power assumptions, by enabling the dominant view of the globe to be questioned and hegemonic projections turned upside down. The figure of the jester tempts the reversal of ideas of wisdom and foolishness when it comes to viewing the world. This is then a decentred, disembodied view that asserts the importance of suspending certainty in order to be open to the Other. It certainly speaks to a tradition and history of cosmopolitan thought, but not in a sense of coming from a standpoint acknowledged to be 'civilised'. In this sense, it can be usefully likened to critical cosmopolitanism; and seen as a vehicle through which to further advance discussions around what exactly such critical cosmopolitanism might entail.

\section{Conclusion - the Fool's Cap map and its implications for critical cosmopolitanism}

This article has attempted to reinstate an undeniably Renaissance atlas via the FCM, in order to proffer a vehicle for furthering discussions about the nature of critical cosmopolitanism and the emancipatory potential of what Sklair refers to as 'generic globalization'. Despite Nussbaum's wellknown and well-intentioned attempt to reinvigorate Kantian cosmopolitanism, grasping the potential for critical cosmopolitanism to engage with generic globalization requires a shift from Stoic to neoStoic thinking. This is the case because it is only with a deeper self-reflection via a decentred subject, that an encounter with the 'Other' can be recognized as a moment in which that Other is no longer Other in a straight-forward way (as Rumford illustrates).

Neo-stoicism places a high value on self-reflection and questioning; hence the map mocks the political 
events of the day, in a manner that aims to draw attention to the foolishness of those in power. It disavows a view of global citizenship in which those who are 'rational' and 'cosmopolitan' and 'liberal' educate those who are not in their (superior) ways - the figure of the jester tempts the reversal of ideas of wisdom and foolishness.

The de-centred positionality of the FCM can provide a way of turning the gaze onto ourselves and in doing so picking apart the apparently straight-forward pairing of globalization, with cosmopolitanism, 'civilisation', reason, the West, capitalism, and democracy. The Western view of globalization in the hands of those in power, is often one that very quickly falls into a civilizing rhetoric. The fools map can be interpreted as questioning this particular version of the civilizing rhetoric. Questioning the all-tooeasy link between Cicero's 'sweet reason', via Montesquieu's 'doux commerce', to Jospeh Nye's soft power, the Western nations as holders of the keys to just war and appropriate cultural attitudes.

The Fool's Cap map is against Reason with a capital R, but not against reason or rationality as Cicero understood it (Neo-Stoic, Ciceronian-inspired ideals of reason, tolerance, and cosmopolitan civic virtue ran as a significant thread through the history of Renaissance cosmography and geographical iconography. Cosgrove, 2003, p. 866). It is perhaps a weak compromise, but in its poetic elegance it certainly serves to undermine, then and now, the rhetoric of those in power and their version of belonging to a global 'family' and behaving in 'civilised' ways. It is arguably still rooted in a project that seeks to promote certain values for sure, and it still has a conception of what is civil rooted in Christianity (albeit very tolerant for non-Christian others), but it is about disinterested contemplation of oneself. As a vehicle for discussions on critical cosmopolitanism, it allows for cosmopolitanism to be placed outside of normalized values such as those of capitalist globalization. In doing so it might enable an unravelling of the apparently straight-forward linkages between cosmopolitanism, globalization, the West, capitalism, and even democracy.

\section{Notes}

1. See Harley's article 'Deconstructing the map', 1989.

2. Giorgio Mangani is one of the few scholars to have worked on the Fool's Cap map and this article therefore draws heavily upon his work.

3. This rhetorical concept had been revived by Giulio Camillo's memory theatre of 1550 and realized in architectural designs such as the Teatro Olimpico constructed at Vicenza in 1580 and the floating theatrum mundi used in Venetian humanist ceremonial (Cosgrove, 1993).

4. Delanty argues that cosmopolitanism has been a response to the experience of war and violence in the twentieth $\mathrm{He}$ asserts,

the emergence of cosmopolitanism after 1945 - as reflected in developments such as the idea of crimes against humanity, the UN Declaration of Human Rights, the general movements towards world-wide democratization, and the project of European integration - was in many ways shaped by the widely felt need to find global solutions based on dialogue rather than on violence (2012, p. 43).

5. It was Ortelius's atlas which became the model at this point in history, as opposed to Mercator's parallel, but unfinished project, despite the fact the latter is perhaps more famous today as the forerunner of the contemporary atlas.

6. In Antwerp, Ortelius found himself at the centre of this argument. This, at a time when 
Mercator's imprisonment for heresy had already proven the extent to which cosmographers were especially exposed, due to the atlas as a form providing the book of creation as a parallel text to biblical scripture. See Crane, 2002, for more details.

7. During the Reformation Erasmus was critical of the Catholic Church and called for reform, but was careful not to side with Luther and the Protestants. He emphasized a middle road that maintained an emphasis on the Catholic doctrine of free will, despite the rejection of this by some reformers in favour of predestination.

8. See Nussbaum, 1997, pp. 5-6 in which she argues that Kant's Perpetual Peace is a profound defence of cosmopolitan values, and is profoundly influenced by stoic ideas such as the worldcitizen. Such thinking was inspired by the Cynics who believed a person should first and foremost be affiliated with rational humanity, and only then with ties of class, status, nationality, or gender. The Stoics built on this view, creating the idea of the world-citizen who dwells in both the local community of their birth, and the community of humanity; the latter being fundamental to moral and social obligations.

9. Other critics include (Appiah, 1996, pp. 21-29; Bhabha, 1996, pp. 191-207; Robbins, 1998, pp. 1-19).

10. As Cosgrove argues, Enlightenment cosmopolitanism was powerfully articulated by Immanuel Kant in his essay on Perpetual Peace and became a significant element of the humanitarian tradition of modern thought in the second half of the twentieth century, underpinning such projects as Esperanto, Amnesty International, the League of Nations, and the United Nations Organization (especially UNESCO). Throughout, the Western cosmopolitan tradition has been closely connected to the idea and image of the globe, and thus to such forms of geographical representation as the world map and the atlas (see Cosgrove 2001, Apollo's Eye).

\section{Acknowledgements}

My thanks go to those who read and advised on this article, including the peer reviewers. 


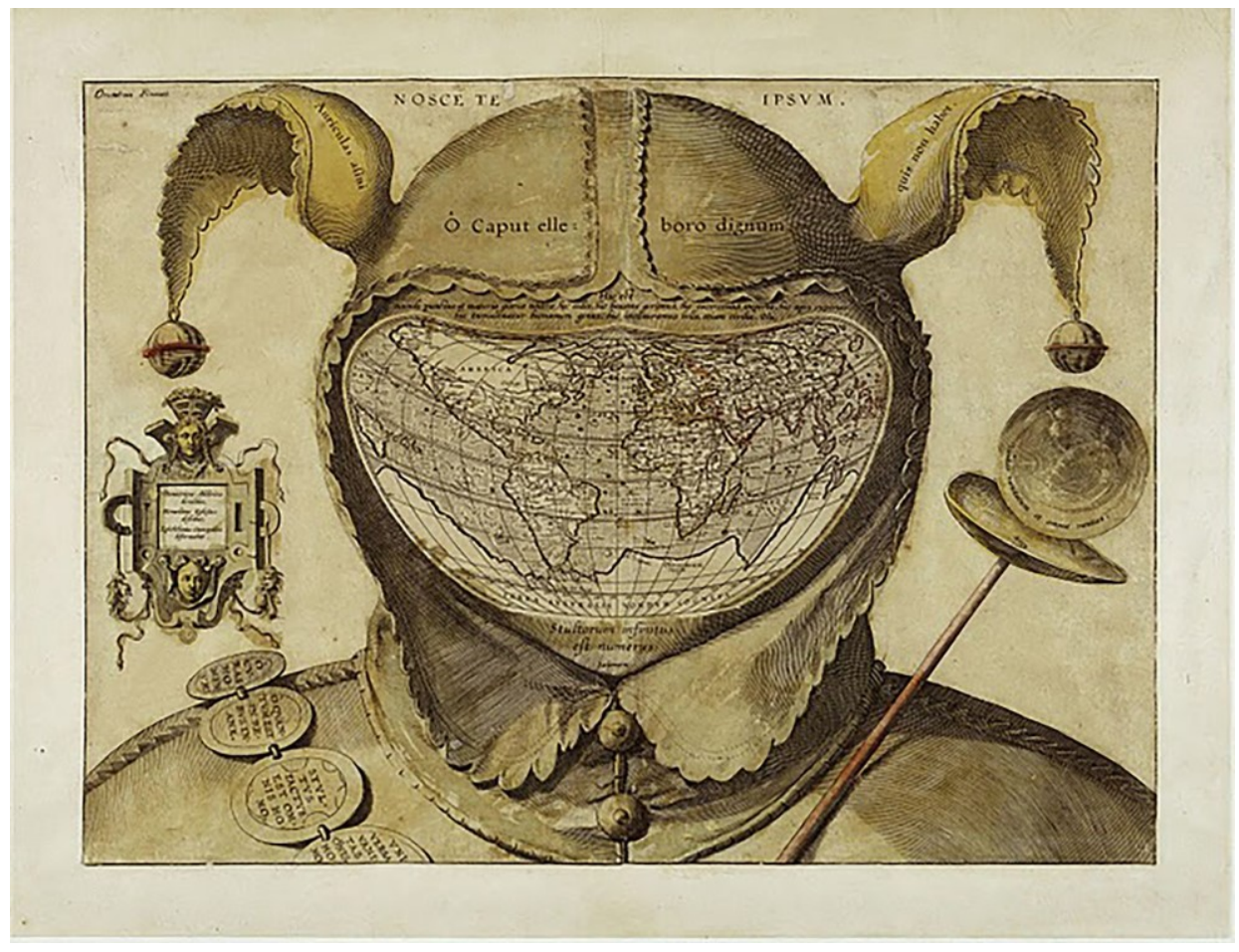

Figure 1. The Fool's Cap map. 

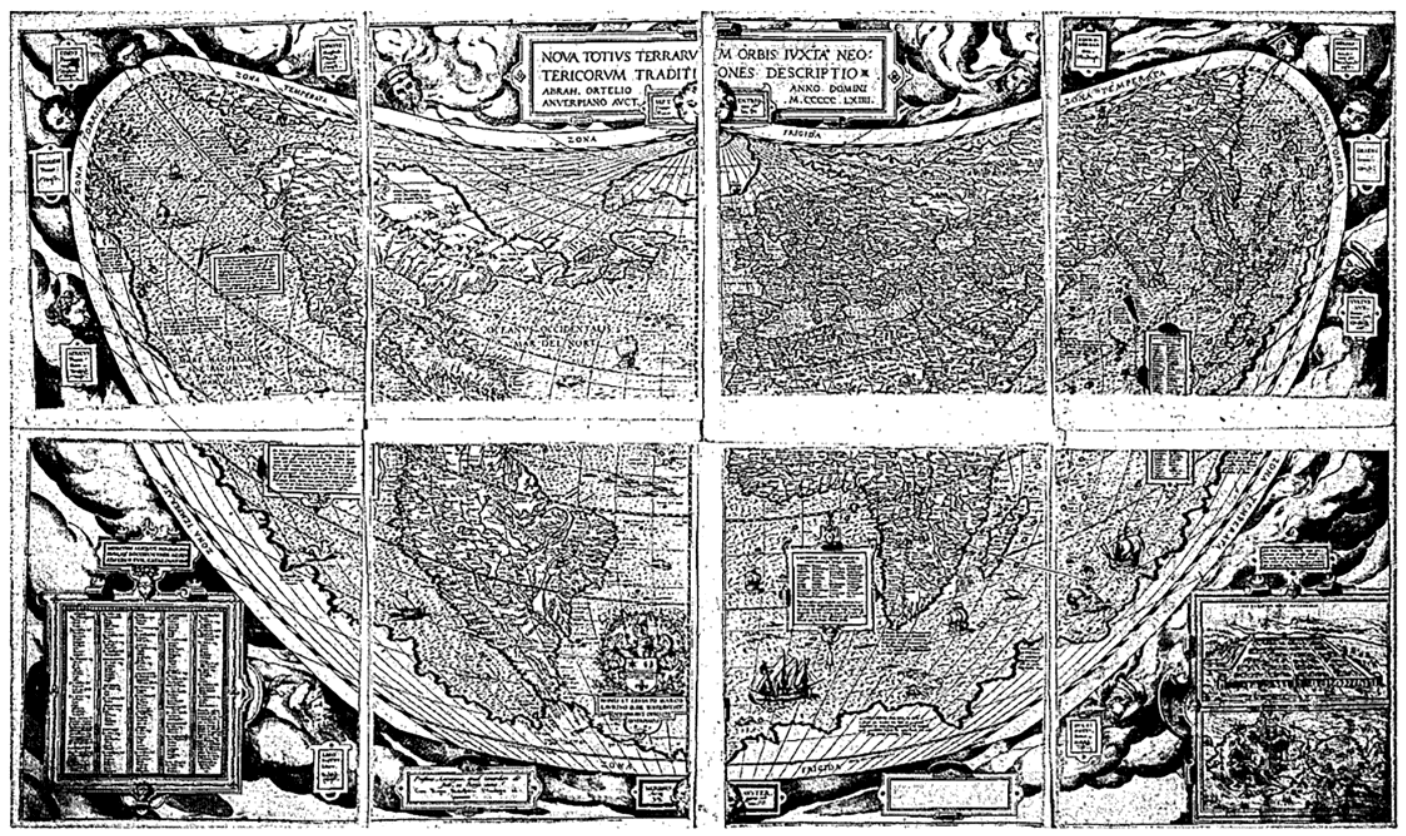

Figure 2. Abraham Ortelius's 1564 map of the world. 


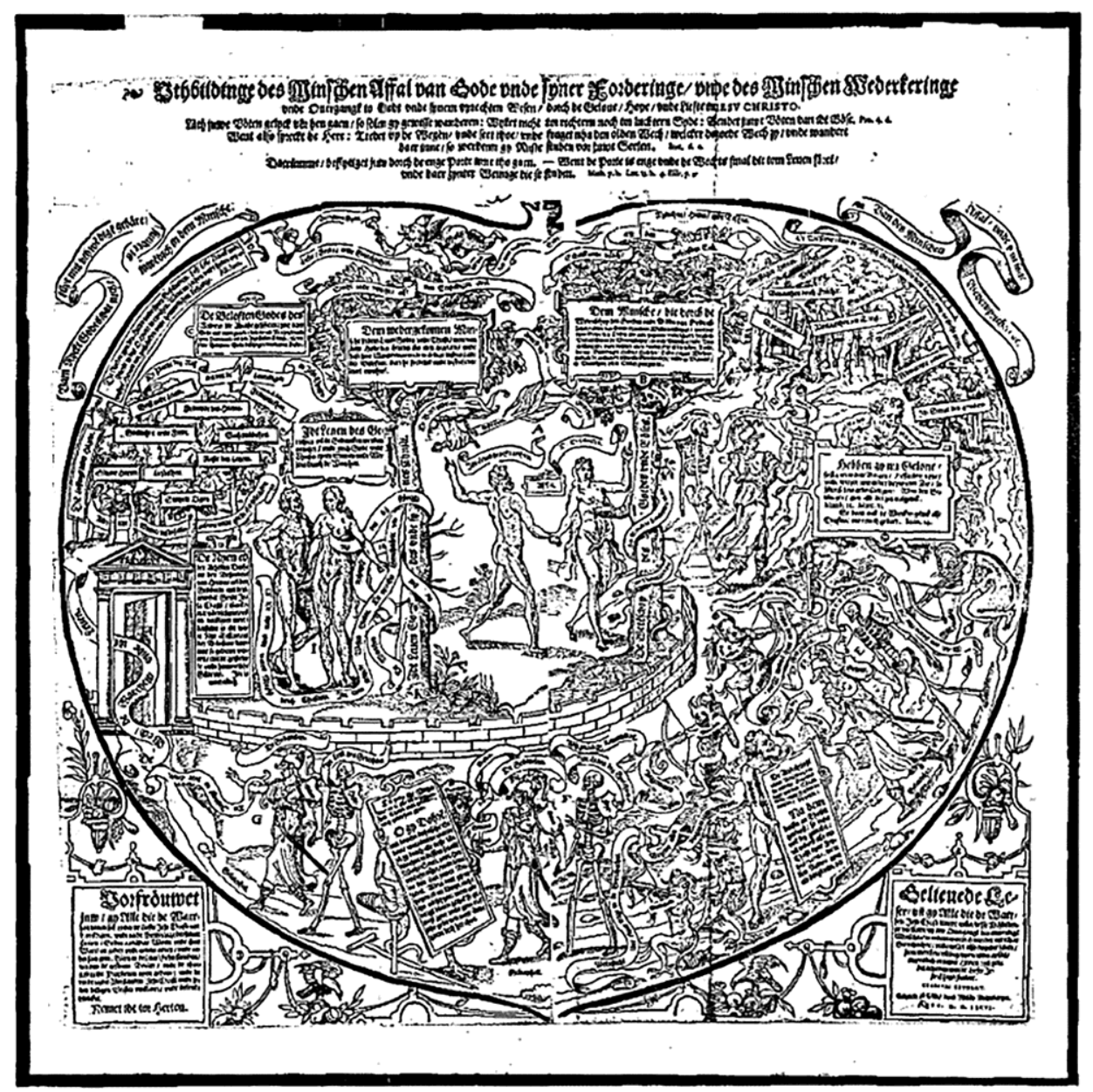

Figure 3. Niclaes Bombarghen's 1576 devotional image. 